\author{
Marquette University \\ e-Publications@Marquette
}

$1-2001$

\title{
Synthesis of cyclopropanes via organoiron methodology: preparation of 2-(2'-carboxy-3'-ethylcyclopropyl)glycine
}

Kamil Godula

William Donaldson

Marquette University, william.donaldson@marquette.edu

Follow this and additional works at: https://epublications.marquette.edu/chem_fac

Part of the Chemistry Commons

\section{Recommended Citation}

Godula, Kamil and Donaldson, William, "Synthesis of cyclopropanes via organoiron methodology: preparation of 2-(2'-carboxy-3'-ethylcyclopropyl)glycine" (2001). Chemistry Faculty Research and Publications. 72.

https://epublications.marquette.edu/chem_fac/72 
Marquette University

\section{e-Publications@Marquette}

\section{Chemistry Faculty Research and Publications/College of Arts and Sciences}

This paper is NOT THE PUBLISHED VERSION; but the author's final, peer-reviewed manuscript. The published version may be accessed by following the link in the citation below.

Tetrahedron Letters, Vol. 42, No. 2 (January 8, 2001): 153-154. DOI. This article is (C) Elsevier and permission has been granted for this version to appear in e-Publications@Marquette. Elsevier does not grant permission for this article to be further copied/distributed or hosted elsewhere without the express permission from Elsevier.

\section{Synthesis of Cyclopropanes Via Organoiron Methodology: Preparation of 2-(2'-carboxy-3'- ethylcyclopropyl)glycine}

\section{Kamil Godula}

Department of Chemistry, Marquette University, Milwaukee, WI

William A. Donaldson

Department of Chemistry, Marquette University, Milwaukee, WI

\footnotetext{
Abstract

A route to 1,2,3-trisubstituted cyclopropanes has been developed. The relative stereochemistry at the three cyclopropane centers is established by nucleophilic attack on the pentadienyl ligand on the face opposite to iron and subsequent oxidatively induced reductive elimination with retention of configuration. This methodology was applied to the synthesis of 2-(2'-carboxy-3'-ethylcyclopropyl)glycines. The diastereomeric glycine dimethyl esters are separable as their diphenylmethylene imines.

The conformationally restricted glutamate analogs $\left(2 S, 1^{\prime} S, 2^{\prime} S, 3^{\prime} R\right)$ - and $\left(2 R, 1^{\prime} S, 2^{\prime} S, 3^{\prime} R\right)$-ECCG's $\mathbf{5}$ a and $\mathbf{5} \mathbf{b}$ were prepared in five steps (17 and $15 \%$ yield, respectively) from (pentadienyl) Fe(CO) ${ }_{3}{ }^{+}(1 R)-6$.
} 


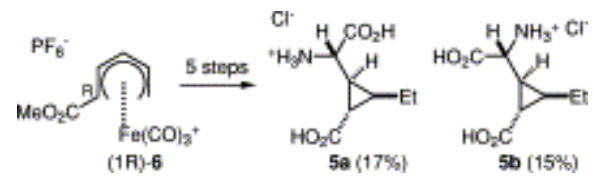

I-Glutamic acid is the major excitatory neurotransmitter for a wide variety of receptors in mammalian systems. ${ }^{1}$ The selective activation of different glutamate receptors may depend on recognition of a particular conformer of this flexible molecule. For this reason, the synthesis and evaluation of conformationally restricted 2-(2'-carboxycyclopropyl)glycines has led to the discovery of ligands with mGluR specificity. ${ }^{2}$ In particular the extended conformation, as exemplified by compounds $\mathbf{1 - 4}$, is believed to be a requirement for binding to the mGluR1 and mGluR2 receptors, while the presence and electronic nature of the 3 '-substituent may distinguish between agonist and antagonist activity. ${ }^{3}$ As part of our overall program on the development of a novel ironmediated formation of substituted cyclopropanes, we herein report on the preparation of 2-(2'-carboxy-3'ethylcyclopropyl)glycines, $\left(2 S, 1^{\prime} S, 2^{\prime} S, 3^{\prime} R\right)-5$ a and $\left(2 R, 1^{\prime} S, 2^{\prime} S, 3^{\prime} R\right)-5 \mathbf{b}$.

We have previously reported that the nucleophilic attack of malonate anions to (1-methoxycarbonylpentadienyl) $\mathrm{Fe}(\mathrm{CO})_{3}{ }^{+}$( (ac-6) proceeds predominantly at an internal carbon, on the face of the pentadienyl ligand opposite to iron, to afford (pentenediyl)iron complexes (rac-7) (Scheme 1). ${ }^{4 a}$ Furthermore, oxidatively induced-reductive elimination of rac-7 gives the vinylcyclopropanecarboxylate $\mathrm{rac}-\mathbf{8} .^{4 \mathrm{~b}}$ It was envisioned that this sequence of reactions might be applicable to the synthesis of 2-(3'-substituted-2'carboxycyclopropyl)glycines.

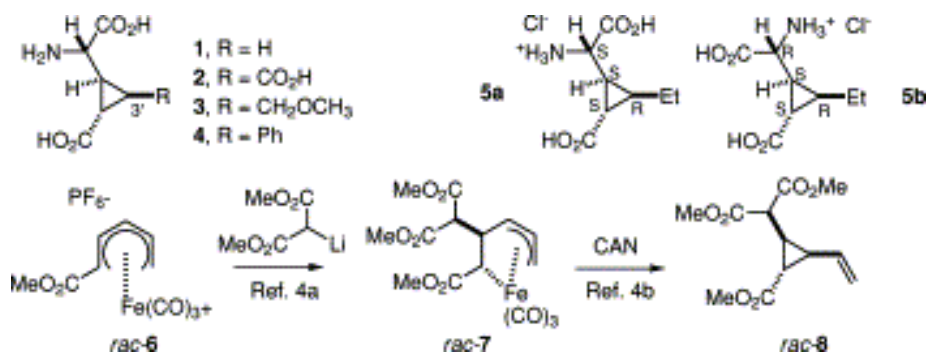

Scheme 1.

Reaction of rac- 6 with the anion derived from methyl nitroacetate gave the (pentenediyl)iron complex rac$\mathbf{9 a} / \mathbf{b}$ as a mixture of diastereomers (Scheme 2). Treatment of $r a c-9 a / b$ with CAN gave $r a c-10 a / b$. The relative stereochemistry about the cyclopropane ring in $10 \mathrm{a} / \mathrm{b}$ was assigned as indicated on the basis of the magnitude of the vicinal couplings $\left(J_{1^{\prime}-2^{\prime}}=J_{2^{\prime}-3^{\prime}}=5.3 \mathrm{~Hz}\right){ }^{5}$ Reduction of $10 \mathrm{a} / \mathbf{b}$, followed by reaction with benzophenone imine $^{6}$ gave a mixture of rac-11a and $r a c-\mathbf{1 1} \mathbf{b}$, which were separable by column chromatography. The structure of rac-11a was confirmed by single-crystal X-ray analysis. ${ }^{7}$ Beginning with $(1 R)-6,{ }^{8}$ this sequence of reactions gave (-)-11a and $(+)-\mathbf{1 1} \mathbf{b}$. The $2 S$ configuration (-)-11a was assigned by comparison of the sign of its specific rotation with that of a series of $13 \mathrm{~N}$-diphenylmethylene imines of I-amino esters. ${ }^{6 b-e}$ Both (-)-11a and (+)11b were assessed to be $>80 \%$ ee by ${ }^{1} \mathrm{H}$ NMR spectroscopy in the presence of $\mathrm{Eu}(\mathrm{hfc})_{3}\left(\mathrm{CDCl}_{3}\right)$. Separate hydrolysis of $(-)-\mathbf{1 1} \mathbf{a}$ or of $(+)-\mathbf{1 1} \mathbf{b}$ gave the cyclopropylglycine hydrochloride salts $\mathbf{5 a}$ or $\mathbf{5 b}$ in excellent yield.

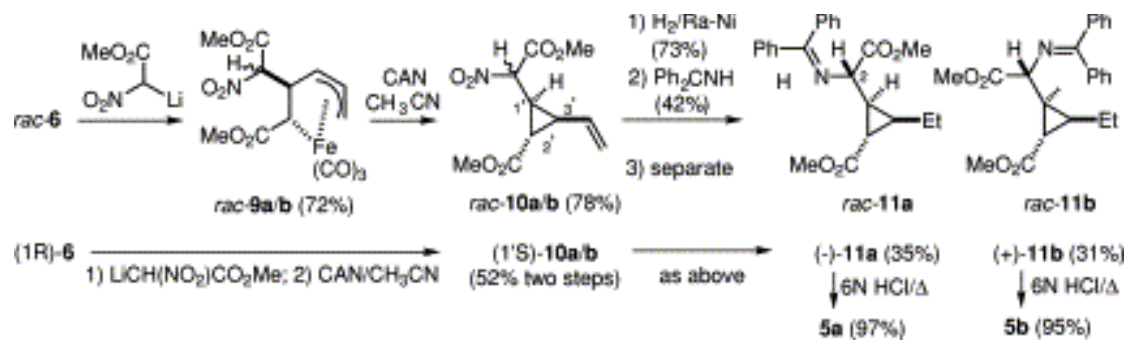

Scheme 2 . 
In summary, a route to 2-(2'-carboxy-3'-ethylcyclopropyl)glycines has been developed. Attempts to prepare other conformationally restricted glutamate analogs from $10 \mathrm{a} / \mathrm{b}$ will be reported in due course.

\section{Acknowledgements}

Financial support for this work was provided by the National Institutes of Health (GM-42641) and the Petroleum Research Fund (34297-AC1). The authors are grateful to Professor Robin Polt, University of Arizona, for stimulating discussions.

\section{References}

1. P.J. Conn, J.-P. Pin. Annu. Rev. Pharmacol. Toxicol., 37 (1997), pp. 205-237

2. (a) Kurokawa, N.; Ohfune, Y. Tetrahedron Lett. 1985, 26, 83-84. (b) Yamanoi, K.; Ohfune, Y. Tetrahedron Lett. 1988, 29, 1181-1184. (c) Pellicciari, R.; Natalini, B.; Marinozzi, M.; Monahan, J. B.; Snyder, J. P. Tetrahedron Lett. 1990, 31, 139-142. (d) Sagnard, I.; Sasaki, N. A.; Chiaroni, A.; Riche, C.; Potier, P. Tetrahedron Lett. 1995, 36, 3149-3152. (e) Shimamoto, K.; Ohfune, Y. J. Med. Chem. 1996, 39, 407423. (f) Pellicciari, R.; Marinozzi, M.; Natalini, B.; Costantino, G.; Luneia, R.; Giorgi, G.; Moroni, F.; Thomsen, D. J. Med. Chem. 1996, 392, 2259-2269. (g) Chavan, S.; Venkatraman, M. S.; Sharma, A. K.; Chittiboyina, A. G. Tetrahedron Lett. 1996, 37, 2857-2858. (h) Ma, D.; Ma, Z. Tetrahedron Lett. 1997, 38, 7599-7602. (i) Pellicciari, R.; Marinozzi, M.; Costantino, G.; Natalini, B.; Moroni, F.; PellegriniGiampietro, D. J. Med. Chem. 1999, 42, 2716-2720; (j) Ma, D.; Cao, Y.; Yang, Y.; Cheng, D. Org. Lett. 1999, 1, 285-287; (k) Mazón, A.; Pedregal, C.; Prowse, W. Tetrahedron 1999, 55, 7057-7064.

3. N. Jullian, I. Barbet, J.-P. Pin, F.C. Acher. J. Med. Chem., 42 (1999), pp. 1546-1555

4. (a) Donaldson, W. A.; Shang, L.; Tao, C.; Yun, Y. K.; Ramaswamy, M.; Young, V. G. J. Organomet. Chem. 1997, 539, 87-98. (b) Yun, Y. K.; Donaldson, W. A. J. Am. Chem. Soc. 1997, 119, 4084-4085. For other recent syntheses of 1,2,3-trisubstituted cyclopropanes see: (c) Taylor, R. E.; Schmitt, M. J.; Yuan, H. Org. Lett. 2000, 2, 601-603; (d) Boehm, C.; Schinnerl, M.; Bubert, C.; Zabel, M.; Labahn, T.; Parisini, E.; Reiser, O. Eur. J. Org. Chem. 2000, 2955-2965.

5. For cyclopropanes, typically $J_{\text {cis }}=7-13 \mathrm{~Hz}, J_{\text {trans }}=4-9 \mathrm{~Hz}$. Silverstein, R. M.; Bassler, G. C.; Morrill, T. C. Spectrometric Identification of Organic Compounds, 5th ed.; John Wiley \& Sons: New York, 1991; pp. 221.

6. (a) O'Donnell, M. J. In Encyclopedia of Reagents for Organic Synthesis; Paquette, L. A., Ed.; John Wiley \& Sons: New York, 1995; Vol. 1, p. 293-294. (b) O'Donnell, M. J.; Polt, R. L. J. Org. Chem. 1982, 47, 2663-2666. (c) O'Donnell, M. J.; Cook, G. K.; Rusterholz, D. R. Synthesis 1991, 989-993. (d) Polt, R.; Peterson, M. A.; DeYoung, L. J. Org. Chem. 1992, 57, 5469-5480. (e) O'Donnell, M. J.; Zhou, C.; Chen, N. Tetrahedron: Asymmetry 1996, 7, 621-624.

7. The X-ray structure of rac-11a was determined by Professor Douglas Stephan. Details of this will be reported separately.

8. C. Tao, W.A. Donaldson. J. Org. Chem., 58 (1993), pp. 2134-2143 